\title{
Lithology and Fluid discrimination of Sody field of the Nigerian Delta
}

\section{FINECOUNTRY, SCP; *INICHINBIA, S}

\author{
Department of Physics, faculty of Science, University of Port Harcourt, Choba, Port Harcourt, Nigeria \\ *Corresponding Author Email address: sonny.inichinbia@yahoo.com; sonny.inichinbia@uniport.edu.ng
}

\begin{abstract}
The lithology and fluid discrimination of an onshore Sody field, of the Niger Delta was studied using gamma ray, resistivity and density logs from three wells in the field in order to evaluate the field's reservoir properties. Two reservoir sands (RES 1 and RES 2) were delineated and identified as hydrocarbon bearing reservoirs. The petrophysical parameters calculated include total porosity, water saturation and volume of shale. The results obtained revealed that the average porosity of the reservoir sands, range from $21 \%$ to $39 \%$, which is excellent indicator of a good quality reservoir and probably reflecting well sorted coarse grain sandstone reservoirs with minimal cementation. Water saturation is low in all the reservoirs, ranging from $2 \%$ to $32 \%$, indicating that the proportion of void spaces occupied by water is low, and implying high hydrocarbon saturation. The crossplot discriminated the reservoirs lithologies as sand, shaly sand and shale sequences, except well Sody 2 which differentiated its lithologies as sand and shale sequences and distinguished the reservoirs' litho-fluids into three, namely; gas, oil and brine. These results suggest that the reservoirs sand units of Sody field contain significant accumulations of hydrocarbon.
\end{abstract}

DOI: https://dx.doi.org/10.4314/jasem.v24i8.3

Copyright: Copyright $(\mathbb{C} 2020$ Finecountry and Inichinbia. This is an open access article distributed under the Creative Commons Attribution License (CCL), which permits unrestricted use, distribution, and reproduction in any medium, provided the original work is properly cited.

Dates: Received: 20 May 2020; Revised: 09 July 2020; Accepted: 04 August 2020

Keywords: Reservoir, porosity, net-to-gross, impedance, lithology

This study focuses on an onshore Niger Delta field and is aimed at using well log data to discriminate lithology and fluid properties of reservoirs discovered in the field. The objective of this work include the determination of the depth and thickness, volume of shale, porosity and water saturation of the reservoirs among others. Accurate prediction of lithology and pore fluid is very essential, and also a key challenge to hydrocarbon exploration and development. However, successful identification of the lithology and pore fluid aids in the accurate determination of porosity, saturation, and permeability of the reservoir. Lithology identification of geological beds in the subsurface is fundamental in reservoir characterization, as one cannot predict the fluid content of any geological bed without first of all knowing the lithology that the fluid is associated with. To make accurate petrophysical calculations of reservoir properties such as porosity, clay volume, water saturation, permeability, net pay and reserve volume, the various lithologies of the reservoir interval must be identified and their properties understood. Therefore, a good understanding of the lithology, pore fluid, pore shape, and pore size is fundamental to other petrophysical analysis which is vital to the effective exploration and production of hydrocarbon. The economic viability of a hydrocarbon field is dependent on the quality and accurate determination of the lithology and pore fluid of the reservoir (Short and Stauble 1965; Crain 1986).

\section{MATERIALS AND METHODS}

Suites of well logs such as gamma ray logs, resistivity logs and density logs obtained from three wells on the field were used for this study. The methods described by Omudu and Ebeniro (2007) and Inichinbia et al. (2014) were employed in this study.

Location of the Study Area: The field is located in onshore Niger Delta and consists of three well. Figure 1 is a map that shows the location of the field. Figure 2 shows the positions of the three wells used in this study. Methodology: The well log data used in this work are displayed in Figures 3, 4, and 5. The data consist of suites of logs from the three wells (SODY $1,2 \& 3$ ) found in the field. The logs include gamma ray, calliper, resistivity and density logs. These logs were used to evaluate the petrophysical properties (such as fluid saturation, porosity and volume of shale) of the field. There are various approaches to lithology and fluid determination, but the most reliable is through direct observation of the core sample from the intervals of interest. This process of acquiring core samples from borehole is very expensive; and this necessitated the use of indirect methods to determine 
lithologies and fluid properties through well logging responses.

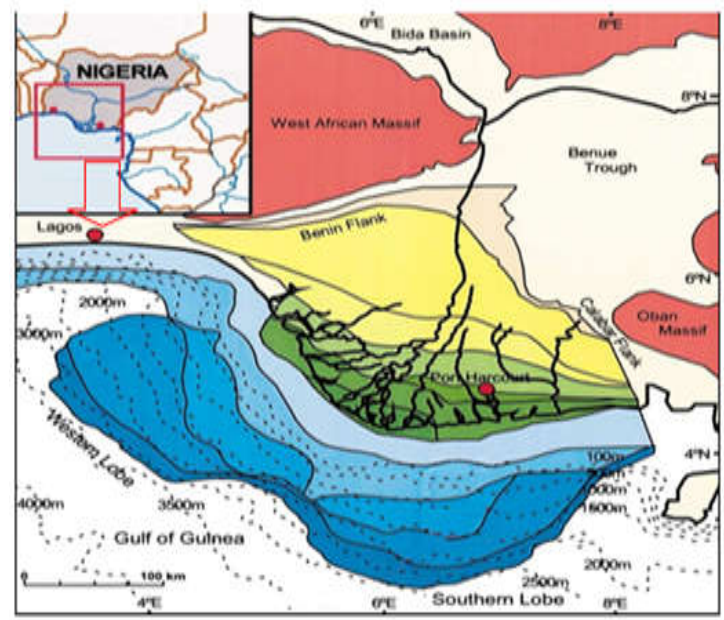

Fig 1. Map of the Niger Delta showing the depobelts and geologic features that bound the delta (Tuttle et al., 1999).

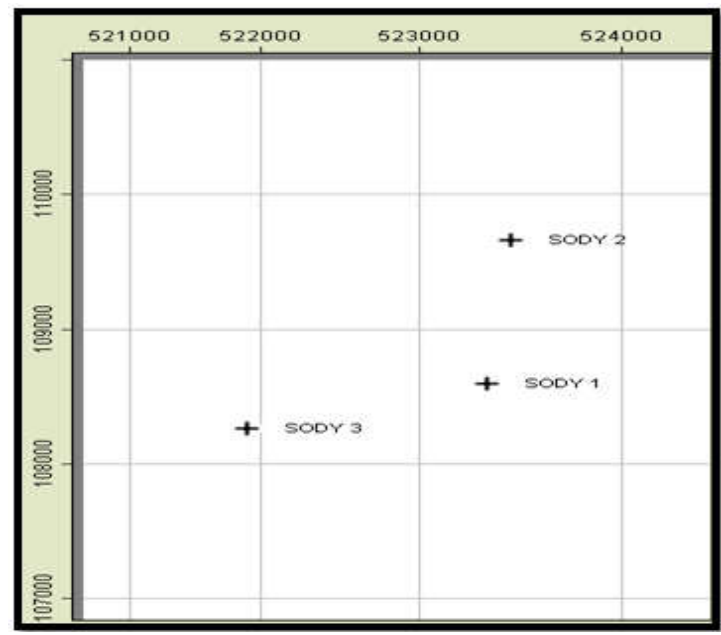

Fig 2. Field location map showing the location of the three wells used in this study

Beds lithology is often predicted using the gamma ray $\log$ response to discriminate lithologies into sand and shale based on their radioactive mineral presence in the formation. Most times this is accompanied by the density $\log$ response from down hole tools. This is made possible since density log measures formation bulk density and photo electric absorption index of the lithologic column penetrated by the borehole. The logs obtained from each of the three wells are displayed in Table 1. These include the following: sonic log, gamma ray logs, resistivity logs, density logs, calliper $\operatorname{logs}$, shale volumetric logs, as displayed in Figures 3, 4 and 5. The inverse of the interval transit times of the sonic logs were used to generate the compressional velocities for each well. These recorded suite of logs were grouped into two categories based on properties that affect seismic wave propagation (e.g., compressional and shear velocity logs and density log) and properties of interest for reservoir description but which indirectly affect seismic wave propagation (e.g., porosity, water saturation, and clay content).

\begin{tabular}{llll}
\multicolumn{4}{c}{ Table 1: Available data } \\
\hline Data & SODY 1 & SDY 2 & SODY 3 \\
\hline Resistivity & $\checkmark$ & $\checkmark$ & $\checkmark$ \\
P-wave log & $\checkmark$ & $\checkmark$ & $\checkmark$ \\
S-wave log & & & $\checkmark$ \\
Caliper & $\checkmark$ & $\checkmark$ & $\checkmark$ \\
Density & $\checkmark$ & $\checkmark$ & $\checkmark$ \\
Gamma Ray & $\checkmark$ & $\checkmark$ & $\checkmark$ \\
\hline
\end{tabular}

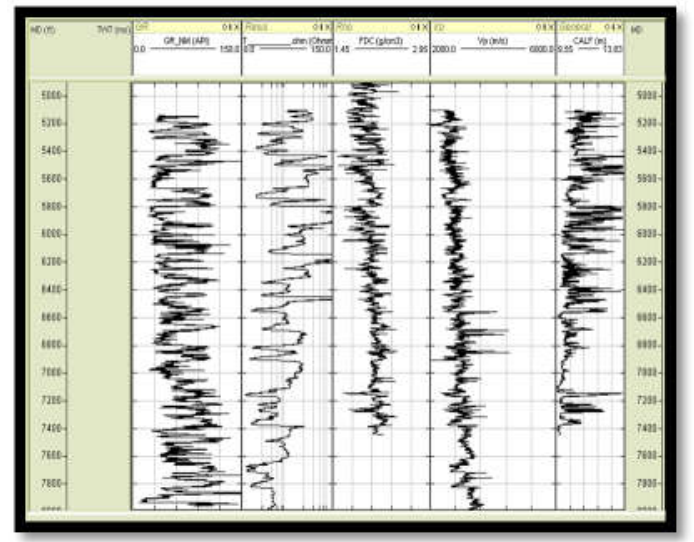

Fig 3. Wireline log data for sody 1 showing suite of logs (black colour) including gamma ray log, resistivity log, density log, pwave $\log$, calliper log and dept in $\mathrm{ft}$.

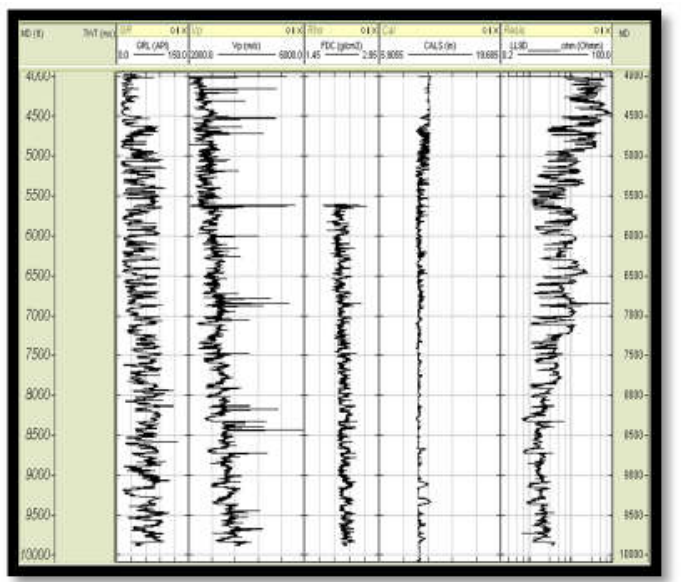

Fig 4. Wireline log data for SODY 2 showing suite of logs (black colour) including gamma ray $\log$, resistivity $\log$, density log, Pwave $\log$, calliper $\log$ and depth in $\mathrm{ft}$.

Data Analysis and Interpretation: These data were analyzed using RokDoc Software, version: 11.5., owned by Ikon Science. Robust and proven petrophysical relations and procedures were employed to determine the various petrophysical properties which include shale volume, fluid saturation and porosity (Omudu and Ebeniro, 2007; Inichinbia et al., 
2014). The analysis was divided into three main stages: Well log editing and conditioning, delineation of the reservoirs in each well, crossplot analysis to discriminate fluid and lithology and petrophysical properties estimation.

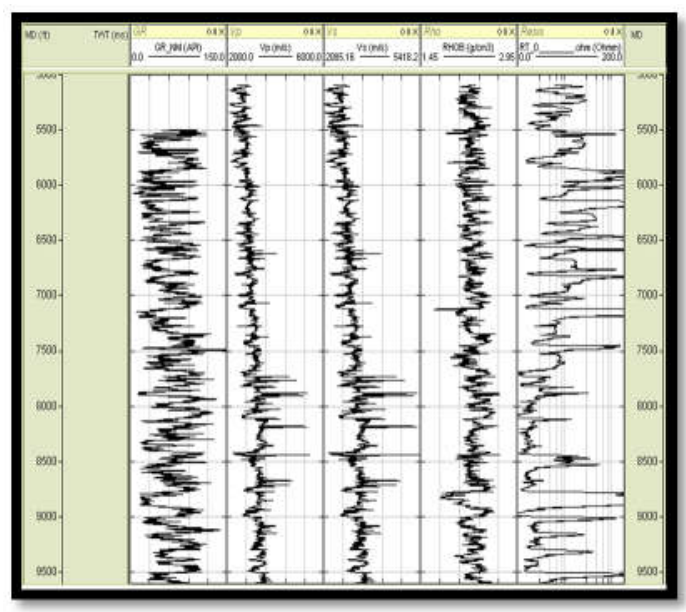

Fig 5. Wireline log data for SODY 3 showing suite of logs (black colour) including gamma ray log, resistivity log, density log, Pwave $\log$, S-wave and depth in $\mathrm{ft}$.

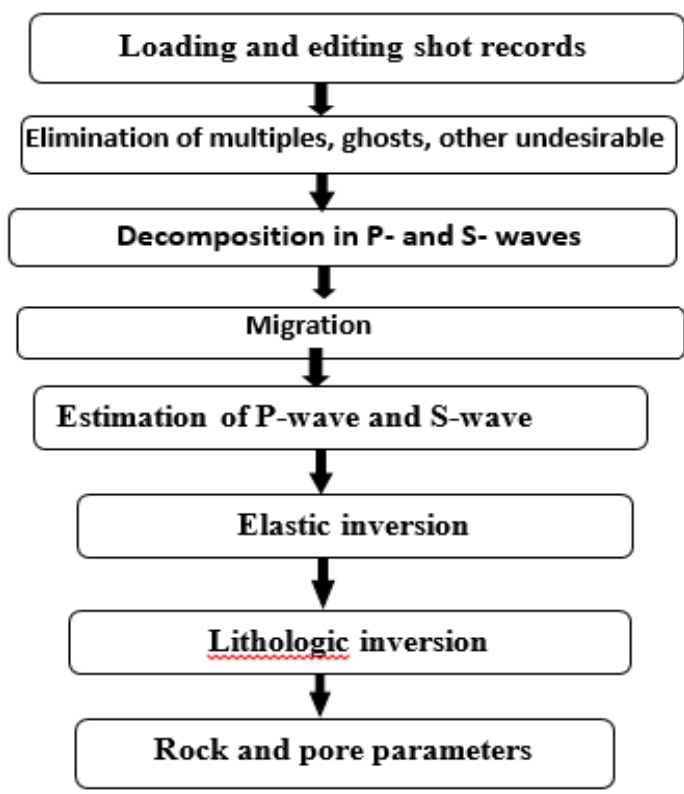

Fig 6. Summary of simplified workflow showing the methods used in the study

The petrophysical properties were determined using different formulae in petrophysics, (Inichinbia et al., 2014; Buriank, 2000; Archie, 1942a\&b). These logs were used to evaluate and analyze the petrophysical properties such as hydrocarbon saturation $\left(S_{h}\right)$, porosity $(\Phi)$, water saturation $\left(S_{w}\right)$. Neutron and density logs each react to both lithology and porosity, so by analyzing these two logs together, one can determine lithology. Although not absolute, because of uncertainties from misinterpretation due to radioactive elements, and low resistivity pay zone in intervals of interest. Combined suite of neutrondensity and deep resistivity logs are used in reservoir fluid prediction in formations. Crossplotting of various rock properties helped to reduce the uncertainties related to the conventional method of predicting lithology and pore fluid and as well provided physical insight on how the elastic properties of different lithofluid classes could be distinguished. The evaluation of these properties is demonstrated through a simplified workflow for this research work as shown in the figure 6.

\section{RESULTS AND DISCUSSION}

The well curves used for the analysis are displayed in Figures 7,8 and 9. The logs include calliper, gamma ray, resistivity, density, and sonic velocity for wells SODY 1, 2 and 3. Two reservoirs (RES1 and RES 2) were delineated in SODY 1,2 and 3. The wells display a sand/shale/sand/shale sequence which is characteristic of the Nigerian Delta formation. The well logs were analysed in terms of lithology using the gamma ray log. Shale lithologies were defined by the high gamma ray value. Shale lithologies cause the deflection of acoustic impedance curve to the right and resistivity to the far left due to their highly conductive nature. Regions showing low gamma ray and high resistivity values are mapped as sand lithologies. The top and base as well as thicknesses of the identified reservoirs of interest are shown in Table 2.

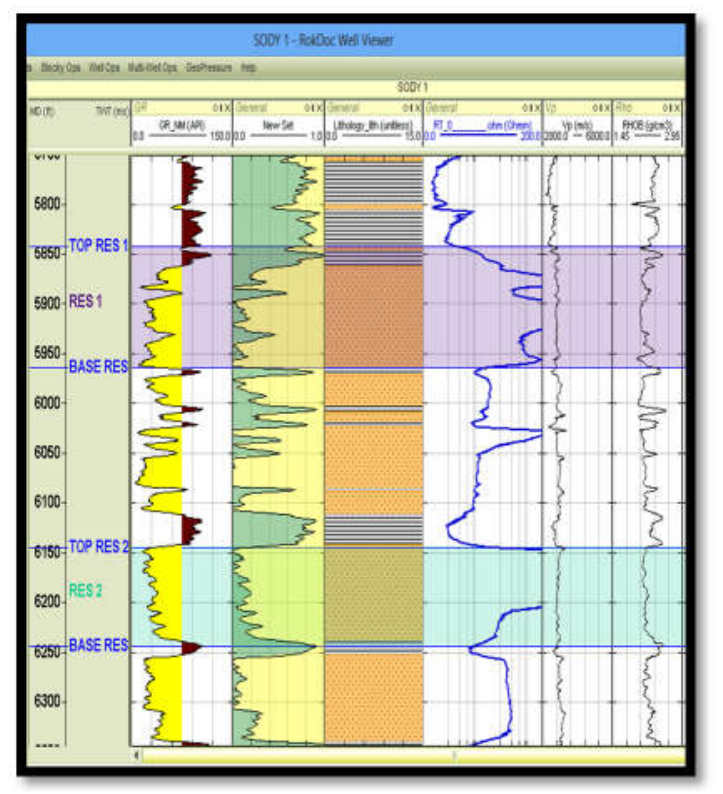

Fig 7. SODY 1 and suite of Logs used in the analysis; gamma ray, resistivity, density, P-wave and S-wave logs and the delineated Reservoirs (RES 1,2). 


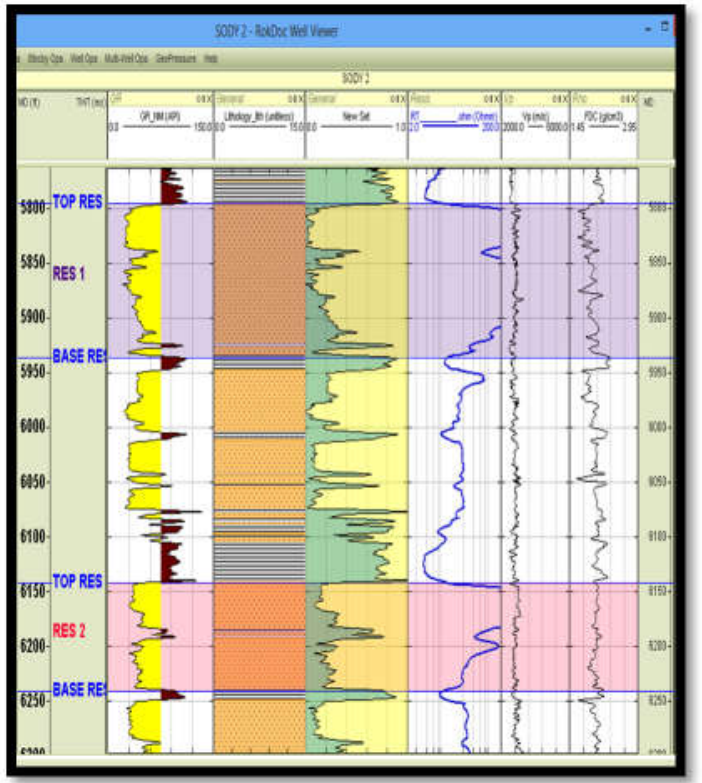

Fig 8. SODY 2 and suite of Logs used in the analysis; gamma ray, resistivity, density, P-wave and S-wave logs and the delineated Reservoirs (RES 1,2).

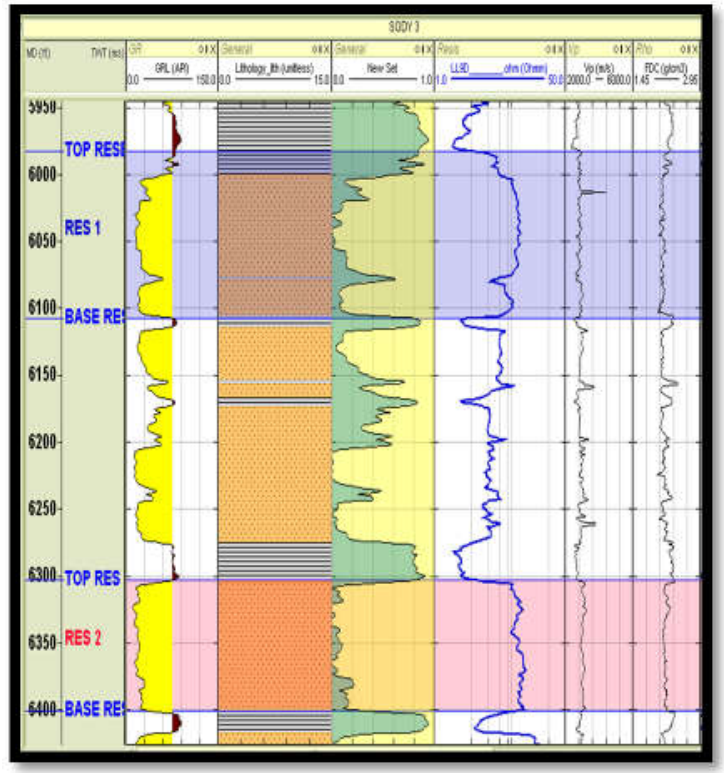

Fig 9. SODY 3 and suite of Logs used in the analysis; gamma ray, resistivity, density, P-wave and S-wave logs and the delineated reservoirs (RES 1,2)

Table 2. Reservoirs of interest for wells Sody 1, 2 and 3

\begin{tabular}{lllll}
\hline Well name & $\begin{array}{l}\text { Reservoir } \\
\text { name }\end{array}$ & $\begin{array}{l}\text { Top md } \\
(\mathrm{ft})\end{array}$ & $\begin{array}{l}\text { Base md } \\
(\mathrm{ft})\end{array}$ & $\begin{array}{l}\text { Thickness } \\
(\mathrm{ft})\end{array}$ \\
\hline SODY 1 & RES 1 & 5843 & 5965 & 122 \\
& RES 2 & 6145 & 6248 & 103 \\
SODY 2 & RES 1 & 5790 & 5940 & 150 \\
& RES 2 & 6140 & 6210 & 100 \\
SODY 3 & RES 1 & 5985 & 6110 & 125 \\
& RES 2 & 6305 & 6406 & 101 \\
\hline
\end{tabular}

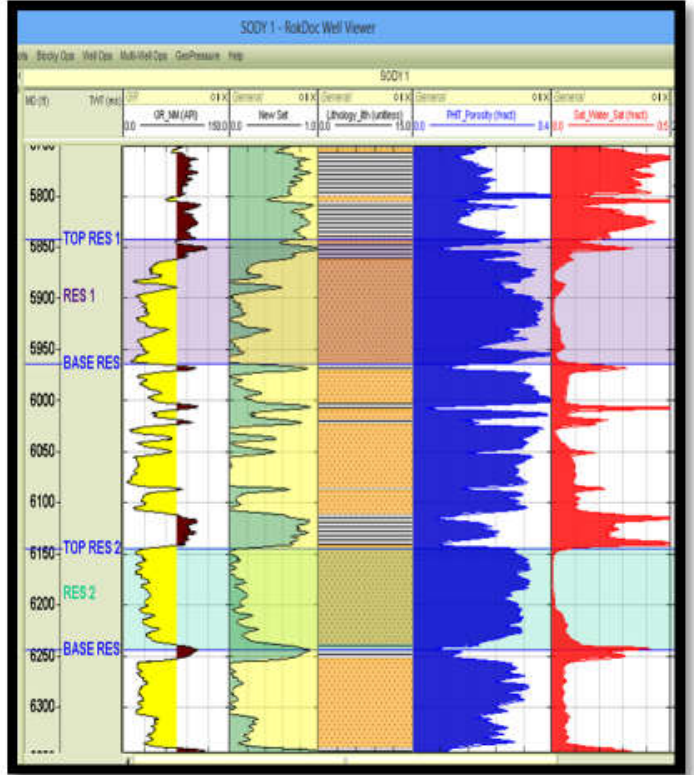

Fig 10. Log curves of the calculated petrophysical properties namely: volume of shale, total porosity and water saturation for SODY 1

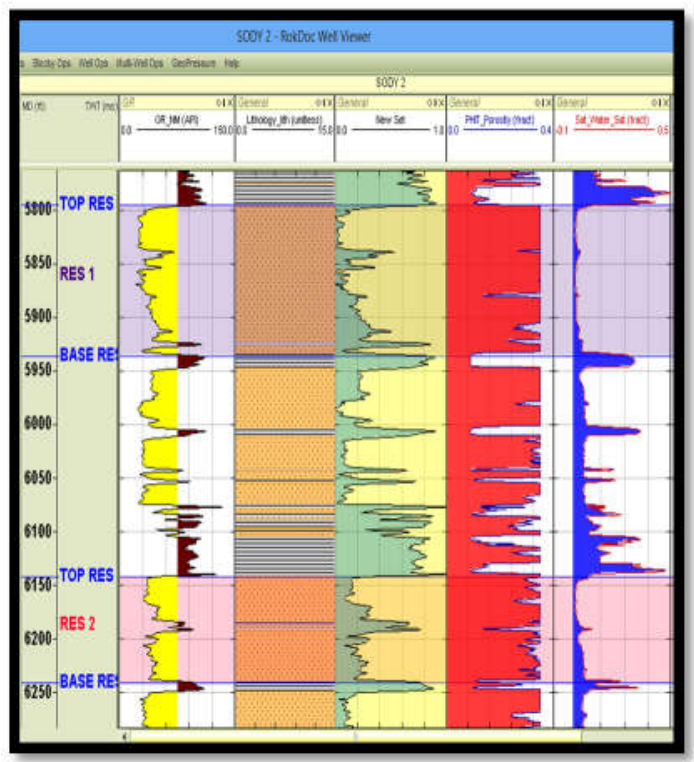

Fig 11. Log curves of the calculated petrophysical properties namely: volume of shale, total porosity and water saturation for SODY 2

The curves of the various calculated petrophysical properties namely; net-to-gross (NTG), gamma ray index, volume of shale, total/effective porosity, and water saturation for the three wells (SODY 1,2 and 3) studied are presented in Figures 10, 11 and 12 respectively. From these figures, it is observed that in the reservoirs, porosity is generally high, and signatures for volume of shale indicate low values, water saturation is also low while permeability is high 
as seen obviously from the log curves. This validates the principles of formation evaluation.

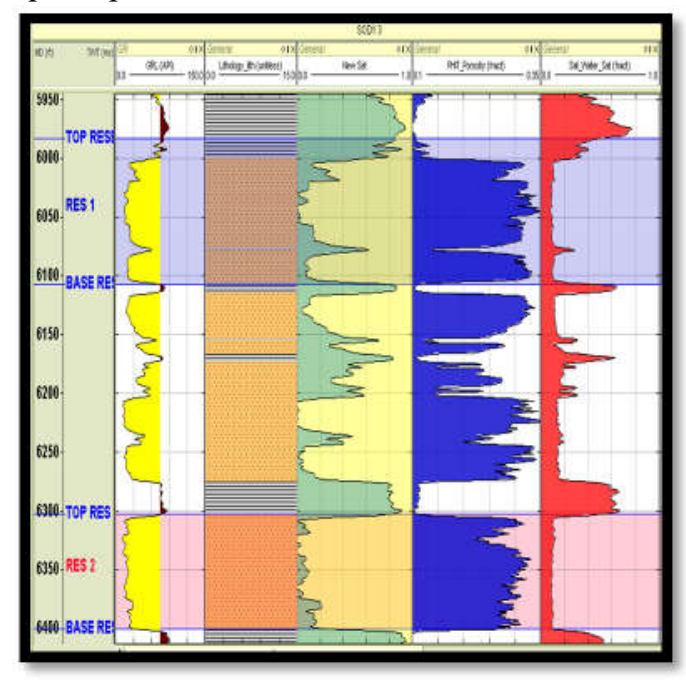

Fig 12. Log curves of the calculated petrophysical properties namely: volume of shale, total porosity and water saturation for SODY 3

The summary of the estimated results are presented in tables (as shown in Tables 3, 4, and 5). Table 3 shows the summary of the average petrophysical parameters of SODY 1, which has two reservoirs (RES 1 \& 2). These are found to be hydrocarbon-bearing. The reservoirs' total porosity were estimated from the density log (RHOB) using the porosity formula and the values range from 0.27 to 0.31 . Thus, indicating a very good reservoir quality and reflecting well sorted coarse grained sandstone reservoirs with minimal cementation. The hydrocarbon saturation of the reservoirs range from 0.85 to 0.91 indicating that the proportion of void spaces occupied by water is low. Consequently, high hydrocarbon saturation and high hydrocarbon production is envisaged.

Table 4 shows the summary of the average petrophysical parameters of SODY 2, which consists of two reservoirs identified as RES $1 \& 2$. These are also hydrocarbon bearing. Porosity of these reservoirs range from 0.21 to 0.31 , water saturation 0.13 to 0.32 and volume of shale 0.27 to 0.36 . These results simply imply that these reservoirs are appreciably porous and permeable. They are also hydrocarbon bearing. Table 5 shows the summary of the average petrophysical parameters of SODY 3, which also consists of three reservoirs identified as RES 1 \& 2 and are hydrocarbon bearing. The average porosity of the wells range from 0.21 to 0.27 , water saturation 0.02 to 0.13 , and volume of shale 0.14 and 0.15 . Also, these results reveal that the reservoirs are appreciably porous and contain high hydrocarbon content. Also, $V_{p} / V_{s}$ versus $\mathrm{P}$-impedance and $V_{p}$ versus density crossplots analyses were done to investigate the sensitivity of the rock properties to fluid and lithology

Table 3. Average petrophysical properties for Well SODY 1

\begin{tabular}{|c|c|c|c|c|c|}
\hline \multicolumn{6}{|c|}{ SODY 1} \\
\hline $\begin{array}{l}\text { Reservoir } \\
\text { name }\end{array}$ & $\begin{array}{l}\text { Top } \\
\text { MD (ft) }\end{array}$ & $\begin{array}{l}\text { Base } \\
\mathrm{MD}(\mathrm{ft})\end{array}$ & $\begin{array}{l}V_{\text {at }} \\
\text { (frac) }\end{array}$ & $\begin{array}{l}\Phi_{\mathrm{T}} \\
\text { (frac) }\end{array}$ & $\begin{array}{l}S_{w} \\
\text { (frac) }\end{array}$ \\
\hline RES 1 & 5843 & 5965 & 0.30 & 0.28 & 0.09 \\
\hline RES 2 & 6145 & 6248 & 0.21 & 0.27 & 0.11 \\
\hline
\end{tabular}

Table 4. Average petrophysical properties for Well SODY 2

\begin{tabular}{llllll}
\hline \multicolumn{7}{c}{ SODY 2 } \\
\hline $\begin{array}{l}\text { Reservoir } \\
\text { name }\end{array}$ & $\begin{array}{l}\text { Top MD } \\
(\mathrm{ft})\end{array}$ & $\begin{array}{l}\text { Base MD } \\
(\mathrm{ft})\end{array}$ & $\begin{array}{l}\mathrm{V}_{\mathrm{ata}} \\
\text { (frac) }\end{array}$ & $\begin{array}{l}\Phi_{\mathrm{T}} \\
\text { (frac) }\end{array}$ & $\begin{array}{l}\mathrm{S}_{\mathrm{w}} \\
(\mathrm{frac})\end{array}$ \\
\hline RES 1 & 5790 & 5940 & 0.27 & 0.27 & 0.13 \\
RES 2 & 6140 & 6210 & 0.36 & 0.21 & 0.28 \\
\hline
\end{tabular}

Table 5. Average petrophysical properties for Well SODY 3

\begin{tabular}{llllll}
\hline \multicolumn{7}{c}{ SODY 3 } \\
\hline $\begin{array}{l}\text { Reservoir } \\
\text { name }\end{array}$ & $\begin{array}{l}\text { Top MD } \\
\text { (ft) }\end{array}$ & $\begin{array}{c}\text { Base MD } \\
\text { (ft) }\end{array}$ & $\begin{array}{l}\mathrm{V}_{\text {ita }} \\
\text { (frac) }\end{array}$ & $\begin{array}{l}\Phi_{\mathrm{T}} \\
\text { (frac) }\end{array}$ & $\begin{array}{l}\mathrm{S}_{w} \\
\text { (frac) }\end{array}$ \\
\hline RES 1 & 5985 & 6110 & 0.14 & 0.36 & 0.13 \\
RES 2 & 6305 & 6406 & 0.15 & 0.39 & 0.02 \\
\hline
\end{tabular}

. The crossplots of sonic velocity, $V_{p}$ versus density colour-coded with gamma ray (Figure 13a, 13b and 13c) differentiated the reservoirs based on lithology, as sand, shale and shaly sand. However, well Sody 2 in Figure 13b differentiated the reservoir into sand and shale zones. Within the target zones, density is also a good lithology indicator, where density ranges of 2.2 $\mathrm{g} / \mathrm{cm}^{3}$ and $1.9 \mathrm{~g} / \mathrm{cm}^{3}$ diagnosed sand, and higher values corresponded to shaly sand and shale. Thus, the crossplots of both $V_{p}$ versus density did a very good separation and distinguished the reservoirs into sand, shaly sand and shale lithology. But in Sody 2 it differentiated the reservoirs into shale and sand zones only. Similarly, the crossplots of $V_{p} / V_{s}$ ratio against acoustic impedance (AI) (see Figure 14a, 14b and $14 \mathrm{c}$ ), distinguished the delineated reservoirs' sands into three zones namely; hydrocarbon zone (blue ellipse), brine zone (orange ellipse) and shale zone (red ellipse) which could be validated from the density colour code or legend. These crossplots show a better hydrocarbon as well as lithology discrimination, indicating that $V_{p} / V_{s}$ versus acoustic impedance attributes will better describe the reservoir in terms of lithology and fluid content. A similar trend is seen for all the three wells. Thus, the crossplot of P-impedance versus $V_{p} / V_{s}$ ratio distinguished the reservoirs into three probable zones namely; hydrocarbon, brine and shale zones. The sand zone contains the hydrocarbon and brine. The results obtained reveal that the average porosity of reservoir sands, ranges from $21 \%$ to $39 \%$, which is very good and close to excellent porosity. This is also indicative of a very good reservoir quality and reflected probably a well sorted coarse grain 
sandstone reservoirs with minimal cementation. Water saturation is low in all the reservoirs, and ranging from $2 \%$ to $32 \%$.

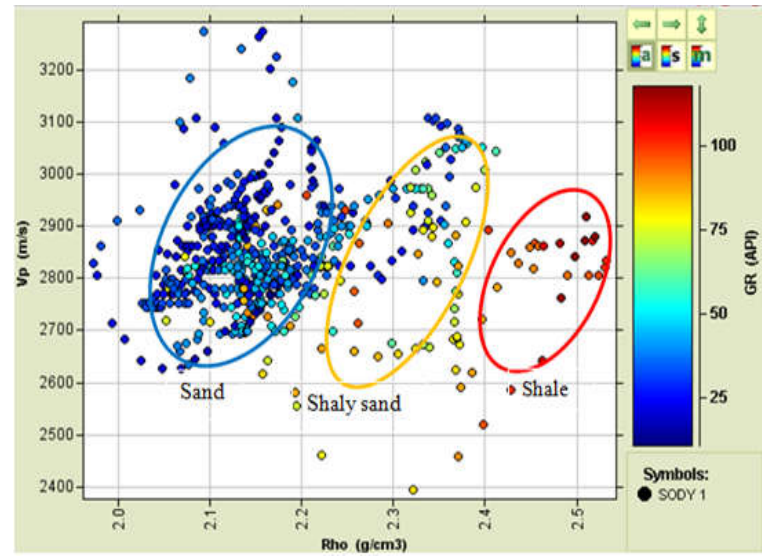

Fig 13a. Crossplot of $V_{p} / V_{s}$ versus density colour-coded to gamma ray for reservoirs $1 \& 2$ for SODY 1

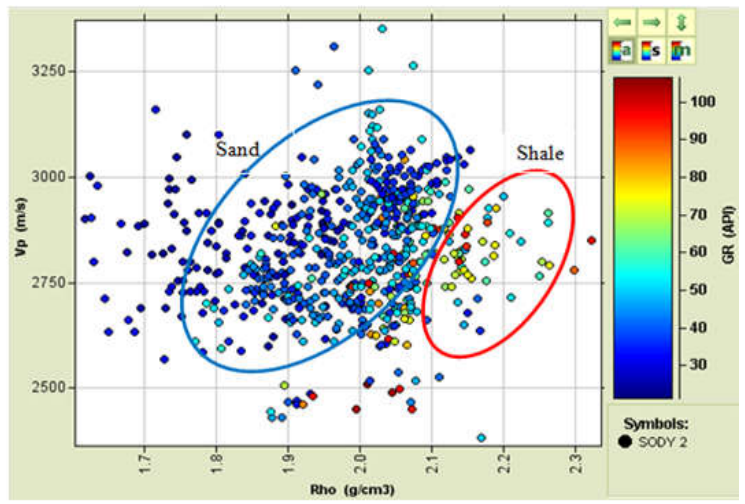

Fig 13b. Crossplot of $V_{p}$ versus density colour-coded to gamma ray for reservoirs $1 \& 2$ for SODY 2

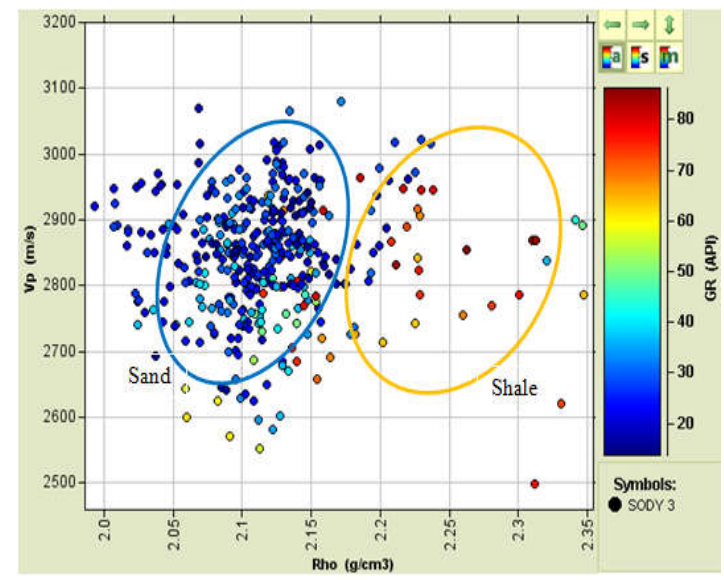

Fig 13c. Crossplot of $V_{p}$ versus density colour-coded to gamma ray for reservoirs $1 \& 2$ for SODY 3 .

This indicates that the proportion of void spaces occupied by water is low, and consequently suggests a high hydrocarbon saturation and a corresponding high hydrocarbon production. The crossplots of $V_{p}$ versus density does a very good separation and distinguished the reservoirs into sand, shaly sand and shale lithology. But in Sody 2 it differentiated the reservoirs into shale and sand zones.

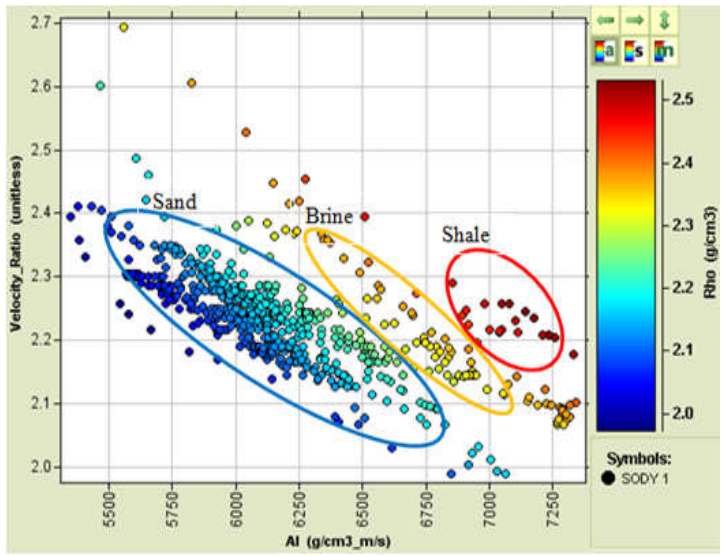

Fig 14a: Crossplot of $V_{p} / V_{s}$ ratio versus Acoustic impedance (AI) for Reservoirs 1 \& 2 for SODY 1

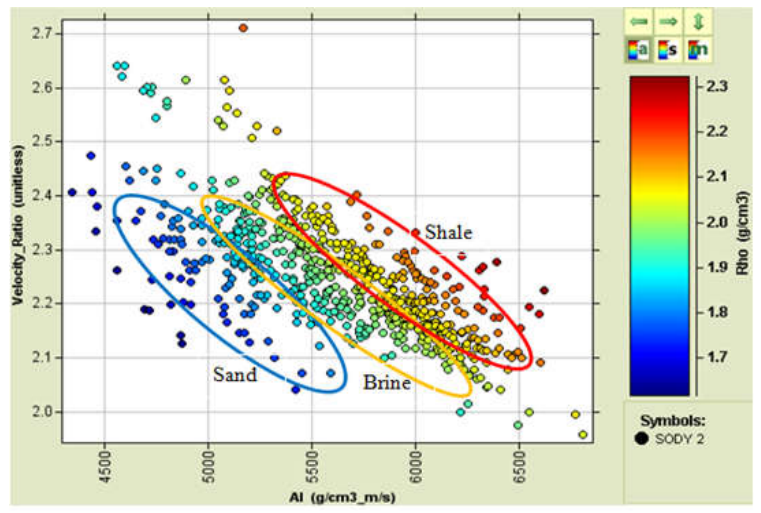

Fig 14b. Crossplot of $V_{p} / V_{s}$ ratio versus Acoustic impedance (AI) for Reservoirs $1 \& 2$ for SODY 2

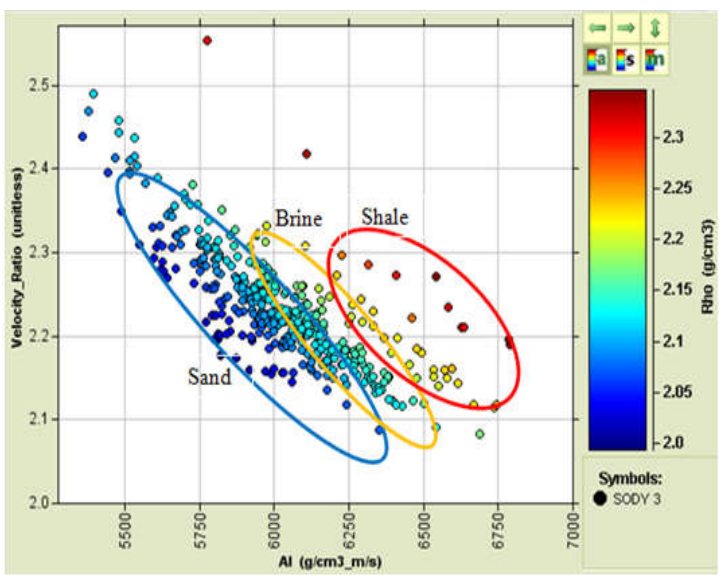

Fig 14c. Crossplot of $V_{p} / V_{s}$ ratio versus Acoustic impedance (AI) for Reservoirs $1 \& 2$ for SODY 3

Also, the crossplot of acoustic impedance (Pimpedance) versus $V_{p} / V_{s}$ ratio distinguished the reservoirs into three zones namely; hydrocarbon, brine and shale zones. The hydrocarbon and brine are 
encased in the sand. The sands of are continuous across the field and are relatively hard sands.

Conclusions: The use of wireline log data to estimate and analyse petrophysical properties of the reservoir rocks of Sody field was successfully carried out to assess the reservoir properties and determine the fluid and lithology of the field. The sands were identified as the hydrocarbon bearing reservoirs in the field. Thus, analysis of the crossplots proved a robust technique in identifying reservoir fluid and lithology.

Acknowledgements: The authors sincerely thank Mr. I.P.C. Okorie and Mr. Mfonobong Akpan for their invaluable assistance through the various stages of this work.

\section{REFERENCES}

Archie, GE (1942a). The Electrical Resistivity as an aid in Determining Some Reservoir Characteristics. J. Petrol. Technol. 5: 54-62.

Archie, GE (1942b). The electrical resistivity log as an aid in determining some reservoir characteristics. Trans. Am. Inst. Mech. Eng. 146: 54-62.

Burianyk, M (2000). Amplitude versus offset and seismic rock property analysis: A primer: The
Canadian Society of Exploration Geophysicists. Recorder. 11: 1- 14.

Crain, ER (1986). The Log Analysis Handbook 1: Quantitative Log Analysis Methods. Penn Well Books, Tulsa, Oklahoma.USA.

Doust, H; Omatsola, E (1990). Divergent/passive Margin Basins, Tulsa, American Association of Petroleum Geologists, AAPG Memoir 48: 239248.

Inichinbia, S; Sule, PO; Ahmed, AL; Hamza, H; Lawal, KM (2014). Petrophysical analysis of among hydrocarbon field fluid and lithofacies using Well Log Data. IOSR J. of Appl. Geol. and Geophys. 2(2): 86-96.

Omudu, LM; Ebeniro, JO (2007). Cross-Plot and Descriptive Statistics for Lithology and Fluid Discrimination: A Case Study from Onshore Niger Delta: Presented at the Annual Meeting of NAPE, Abuja.

Short, KC; Stauble, AJ (1965). Outline of geology of Niger Delta: American Association of Petroleum Geologists. AAPG Bulletin 51(76): 1-779. 